\title{
KONTRIBUSI PENDAPATAN SEKTOR INFORMAL TERHADAP PENDAPATAN RUMAH TANGGA PETANI DI DESA PINABETENGAN UTARA KECAMATAN TOMPASO BARAT
}

\author{
Praise Iroth \\ O. Esry H. Laoh \\ Ribka M. Kumaat
}

\begin{abstract}
The same opportunity to work in the informal sector to encourage farmers to make the decision to allocate the available workforce to be more efficient than that of bulk farm working hours also had a busy time and leisure time. The increased revenue adds the satisfaction level through the increase of consumption and leisure time. This research is to determine the contribution of informal sector income on household income Pinabetengan farmers in the Northern District of West Tompaso. This research was conducted in the village of North Pinabetengan, in June 2015 through December 2015. The data used are primary and secondary data. Primary data is data taken with direct interviews to farmers who have jobs in the informal economy. Secondary data is data taken from North Pinabetengan village office. The analysis has used in this study are presented in tabular form. The main commodities of farmers in the village are corn, beans, peanuts, rice and vegetables and spices. Farm income of farmers is the smallest $R p$ 600,000 and $R p$ 9,800,000 the greatest. The informal sectors has done such as motorcycle taxi, buggy, stalls, food stalls, craftsmen, traders, tailors, pitchman, garage, laundry worker. The lowest Income informal sector is Rp 500,000 and the highest is $R p$ 2,400,000. Results of the analysis showed that the contribution of the informal sector to household income of farmers amounted to $41.10 \%$ with an average farm income in rural sub-district Tompaso Pinabetengan north west Rp . 1,600,833 / month, the average income of informal sector Rp . 1.177 million / month. So that the average total income of Rp . 2717833.
\end{abstract}

Keyword: Contribution, Informal Sector, Income, North Pinabetengan Village, Minahasa

\begin{abstract}
ABSTRAK
Peluang yang sama untuk bekerja di sektor informal mendorong petani membuat keputusan untuk mengalokasikan tenaga kerja yang tersedia menjadi lebih efisien selain itu curah jam kerja usaha tani juga memiliki waktu sibuk dan waktu senggang. Pertambahan pendapatan meningkatkan tingkat kepuasan baik melalui pertambahan konsumsi maupun melalui penambahan waktu senggang Penelitian ini bertujuan untuk mengetahui besarnya kontribusi pendapatan sektor informal pada pendapatan rumah tangga petani di Desa Pinabetengan Utara Kecamatan Tompaso Barat. Penelitian ini dilakukan di Desa Pinabetengan Utara, pada bulan Juni 2015 sampai Desember 2015. Data yang digunakan adalah data primer dan sekunder. Data primer yaitu data yang diambil dengan melakukan wawancara langsung kepada para petani yang memiliki pekerjaan di sektor informal. Data sekunder yaitu data yang diambil dari kantor desa Pnabetengan Utara. Analisis yang digunakan dalam penelitian ini adalah disajikan dalam bentuk table. Komoditas utama petani di desa yaitu jagung, kacang merah, kacang tanah, padi serta sayur dan rempah. Pendapatan usaha tani petani yang paling kecil Rp 600.000 dan yang paling besar Rp 9.800.000. Sektor informal yang dikerjakan yaiutu ojek, bendi, warung, warung makan, tukang, pedagang pasar, tukang jahit, pedagang keliling, bengkel, buruh cuci. Pendapatan sektor informal yang paling rendah Rp 500.000 dan yang paling tinggi Rp. 2.400.000. Hasil analisis menunjukan bahwa kontribusi pendapatan sektor informal terhadap pendapatan rumah tangga petani sebesar $41,10 \%$ dengan rata-rata pendapatan usahatani di desa Pinabetengan utara Kecamatan Tompaso barat Rp. 1.600.833/bulan, rata-rata pendapatan sektor informal Rp. 1.177.000/bln. Sehingga rata-rata total pendapatan Rp. 2.717.833.
\end{abstract}

Kata kunci: Kontribusi, Sektor Informal, Pendapatan, Desa Pinabetengan Utara, Minahasa 


\section{PENDAHULUAN}

\section{Latar Belakang}

Laju pertumbuhan penduduk yang semakin tinggi menyebabkan meningkatnya angkatan kerja. Peningkatan tenaga kerja tidak seimbang dengan kurangnya lapangan pekerjaan di Indonesia. Menurut Lembong (2013) pertanian adalah kegiatan pemanfaatan sumber daya hayati yang dilakukan manusia untuk menghasilkan bahan pangan, bahan baku industri, atau sumber energi, serta untuk mengelola lingkungan hidupnya. Lahan pertanian Indonesia semakin sempit karena dijadikan sebagai lahan industri dan sarana lainnya yang terus menekan hasil pertanian yang semakin terpuruk.

Menurut Arsyad (1999) peranan sektor pertanian dalam pembangunan ekonomi sangat penting karena sebagian anggota masyarakat di negara miskin dan negara sedang berkembang menggantungkan hiidupnya pada sektor tersebut. Sektor pertanian merupakan sektor yang menyerap tenaga kerja tertinggi. Disadari bahwa pengwilayahan komoditas pertanian seluruh daerah pedesaan sangat luas tapi dengan adanya daerah yang memiliki perijinan untuk pengembangan kawasan pemukiman, banyak lahan garapan yang dialokasikan sebagai tempat bermukim, maka ini merupakan masalah yang harus di atasi oleh sector pertanian namun tidak seluruh tenaga kerja dapat diserap oleh sektor pertanian, karena terbatasnya sumber lahan pertanian oleh pembangunan sekitar wilayah pertanian. Secara umum pendapatan petani sekeluarga dapat bersumber dari sektor non pertanian. Alasan yang melatar belakangi pernyataan tersebut berkisar antara kesempatan kerja dan pendapatan antara lain seperti rendahnya pendapatan di sektor pertanian (usaha tani), pekerjaan dan pendapatan usaha tani pada umumnya bersifat musiman, dan usaha dalam pertanian banyak mengandung resiko ketidakpastian. Peranan sektor pertanian bagi masyarakat pedesaan sangat dipengaruhi oleh luas lahan yang merupakan faktor produksi utama petani, rumah tangga yang memiliki lahan garapan sempit, bahkan tidak memiliki lahan akan memperoleh hasil pendapatan yang terbatas untuk kebutuhan rumah tangganya. Permasalahan yang dihadapi rumah tangga petani ini bisa diatasi dengan mencari alternatif kegiatan bekerja diluar sektor pertanian, peluang yang sama untuk bekerja di sektor informal mendorong petani membuat keputusan untuk mengalokasikan tenaga kerja yang tersedia menjadi lebih efisien selain itu jam kerja usaha tani juga memiliki waktu sibuk dan waktu senggang. Pertambahan pendapatan meningkatkan tingkat kepuasan (utility) baik melalui pertambahan konsumsi maupun melalui penambahan waktu senggang (leisure). (Payaman, 1996). Menambah waktu senggang berarti mengurangi jam kerja. Sumbangan pendapatan hasil kerja dari para anggota rumah tangga berasal dari pendapatan bapak, pendapatan ibu dan pendapatan anak akan untuk memenuhi kebutuhan keluarganya. Waktu senggang yang dimiliki tersebut menyebabkan rumahtangga petani mencurahkan waktunya bekerja di luar usahatani selain tidak mengganggu jam kerja petani diasumsikan bahwa dengan tingkat pendapatan usaha tani yang rendah, rumah tangga akan memaksimalkan pendapatannya, meningkatkan kesejahteraan keluarga petani.

Untuk mencukupi kebutuhannya, rumah tangga pedesaan mencurahkan tenaganya dalam berbagai kegiatan nafkah. Sedangkan pendapatan tambahan didefinisikan sebagai penghasilan yang diperoleh rumahtangga dengan mengusahakan kegiatan lain di luar pekerjaan utama (Triyani, 2004). Rumah tangga yang tidak memperoleh pendapatan yang cukup dari usaha tani, tentu saja memerlukan sumbersumber lain untuk menghidupi keluarganya. Sumber-sumber pendapatan ini diperoleh dengan melibatkan diri pada berbagai kegiatan ekonomi baik dalam maupun di luar desa. Setiap anggota rumah tangga yang telah dewasa diharapkan dapat memberi sumbangan bagi pendapatan rumah tangganya. Petani menggunakan pendapatannya untuk memenuhi kebutuhan keluarga dengan melakukan pengeluaran atau konsumsi pangan dan non pangan (Zahri, 2004).

Jenis-jenis pendapatan yang berasal dari luar sektor pertanian umumnya tidak terkait dengan musim dan dapat dilakukan setiap saat sepanjang tahun (Nurmanaf, 2006). Peluang untuk bekerja di luar usaha tani sebagai upaya peningkatan kesejahteraan bagi petani bisa dimulai dengan membuat usaha-usaha baru di sektor informal. Sektor informal merupakan 
lapangan pekerjaan yang diciptakan dan diusahakan sendiri tanpa mengganggu usaha taninya. Masyarakat yang tidak memiliki ketrampilan dan pendidikan yang memadai merupakan komunitas terbesar sebagai pelaku kegiatan ekonomi informal, yang mana untuk memasukinya tidak memerlukan pendidikan formal dan keterampilan yang tinggi, tidak memerlukan surat-surat izin resmi serta modal besar untuk memproduksi barang dan jasa. Sektor informal disini merupakan unit usaha yang diciptakan oleh masyarakat sebagai sarana untuk mencukupi kebutuhan hidup yang dirasakan mereka sulit.

Desa Pinabetengan Utara terletak di kaki gunung soputan juga merupakan jalur pendakian ke gunung soputan dengan ketinggian 800 meter di atas permukaan laut. Komoditas utama yang dibudidayakan oleh petani di desa ini yaitu jagung, brenebon dan kacang tanah. Pertanian adalah mata pencaharian utama di desa Pinabetengan utara. Dalam penelitian ini diketahui bahwa jumlah masyarakat di desa ini memiliki pekerjaan sampingan di sektor informal yang sangat menunjang kesejahteraan pendapatan keluarga. Pekerjaan di sektor informal di lakukan disaat senggang kegiatan usahatani. Pekerjaan di sektor informal terbukti menambah pendapatan serta meningkatkan kualitas hidup masyarakat di desa pinabetengan utara. Usaha sektor informal tersebut meliputi : Penjual sayur, tukang ojek, warung, tukang becak, pembuat kue, kantin, tukang kayu, tukang jahit, bengkel, bakso keliling, tukang cuci, dan lain-lain. Pendapatan yang diterima tersebut pada gilirannya akan mewujudkan kesejahteraan keluarga (Agustina, 1994). Dengan adanya sektor informal membuka pandangan baru terhadap mengkombinasikan kerja untuk lebih efisien menggunakan jam kerja yang ada sebagai dampak dari curah jam kerja rumah tangga petani yang mempunyai waktu senggang sebagai upaya meningkatkan kesejahteraan pendapatan rumah tangga petani

\section{Perumusan Masalah}

Secara umum rumah tangga petani yang berada di pedesaan memiliki pendapatan yang kecil sehingga petani di pedesaan berkaitan erat dengan keadaan kurang mampu atau dikatakan miskin jika tidak bisa memenuhi kebutuhan hidupnya. Masalah petani dalam usaha tani bisa diatasi dengan mencari kegiatan pekerjaan selain sektor pertanian, tanpa mengganggu jam kerja dan memiliki keuntungan untuk meningkatkan kesejahteraan pendapatan rumah tangga petani. Berdasarkan uraian ini maka permasalahan yang diangkat dalam penelitian ini adalah berapa besar kontribusi pendapatan sektor informal pada pendapatan rumah tangga petani di Desa Pinabetengan Utara, Kecamatan Tompaso Barat.

\section{Tujuan}

Penelitian ini bertujuan untuk mengetahui besarnya kontribusi pendapatan sektor informal pada pendapatan rumah tangga petani.

\section{Manfaat Penelitian}

Manfaat penelitian ini adalah dapat memberikan informasi bagi para petani untuk mengetahui besarnya kontribusi pendapatan sektor informal pada pendapatan rumah tangga petani.

\section{METODOLOGI PENELITIAN}

\section{Metode Pengumpulan Data}

Data yang dikumpulkan dalam penelitian ini adalah data primer dan data sekunder. Data primer diperoleh melalui pengamatan dan wawancara secara langsung dengan petani yang melakukan kegiatan usahatani dengan menggunakan kuesioner yang telah dipersiapkan sebelumnya. Data sekunder sebagai data pendukung diperoleh dari berbagai instansi antara lain kantor desa pinabetengan.

\section{Metode Pengambilan Sampel}

Pengambilan sampel dilakukan dengan menggunakan metode (purposive sampling) dimana secara sengaja sampel yang diambil adalah petani di Desa Pinabetengan Utara Kecamatan Tompaso Barat. Jumlah sampel diambil sebanyak 60 petani yang memiliki pekerjaan sampingan di sektor informal.

\section{Konsepsi Pengukuran Variabel}

Variabel yang diukur dalam penelitian ini adalah kontibusi pendapatan sektor informal pada pendapatan rumah tangga petani di desa 
Pinabetengan Utara kecamatan Tompaso Barat. Pengukuran variable dalam penelitia ini dapat dijelaskan sebagai berikut :

1. Umur petani Usia responden yang diukur dalam (tahun)

2. Pendidikan Jenjang pendidikan berdasarkan (SD, SMP, SMA, D3, S1)

3. Luas lahan yang diukur dalam (Ha)

4. Komoditas utama usahatani

5. Pendapatan usahatani dihitung dalam (Rp)

6. Pekerjaan sektor informal

7. Pendapatan sektor informal dihitung dalam (Rp)

8. Kontribusi pendapatan sektor informal yang diukur dalam $(\%)$

\section{Analisis Data}

Analisis yang digunakan dalam penelitian ini adalah analisis deskriptif dengan menggunakan tabel. Analisis deskriptif adalah suatu metode yang meneliti status kelompok manusia, suatu objek, suatu set kondisi, suatu sistem pemikiran, ataupun suatu kelas peristiwa pada masa sekarang. (Nazir, 2003).

Tujuan penelitian deskriptif adalah untuk membuat deskripsi, gambaran atau lukisan secara sistematis, faktual dan akurat mengenai fakta-fakta, sifat-sifat serta hubungan antara fenomena yang diselidiki

\section{HASIL DAN PEMBAHASAN}

\section{Letak dan Luas Wilayah}

Penelitian ini dilakukan di Desa Pinabetengan Utara Kecamatan Tompaso Barat, Kabupaten Minahasa. Desa ini memiliki luas \pm 300 ha, yang terbagi atas 4 jaga. Desa ini terletak di kaki Gunung Soputan juga merupakan jalur pendakian ke gunung soputan dengan ketinggian 800 meter di atas permukaan laut. Desa ini. Suhu rata-rata hariannya sekitar $19^{\circ} \mathrm{C}-26^{\circ} \mathrm{C}$. Adapun batas batas wilayah sebagai berikut: Sebelah utara berbatasan dengan Kawangkoan, sebelah timur berbatasan dengan Desa Tonsewer, sebelah selatan berbatasan dengan Desa Pinabetengan Induk, dan sebelah barat berbatasan dengan Desa Kanonang. Penggunaan lahan di Desa Pinabetengan utara dapat dilihat pada tabel 1. Berikut ini

\section{Tabel 1. Penggunaan Lahan di Desa Pinabetengan Utara}

\begin{tabular}{cccc}
\hline No. & Jenis Lahan & $\begin{array}{c}\text { Luas } \\
\text { Lahan } \\
\text { (ha) }\end{array}$ & $\begin{array}{c}\text { Persenta } \\
\text { si (\%) }\end{array}$ \\
\hline 1 & Tegal/ Ladang & 186 & 62 \\
2 & Pemukiman & 102 & 34 \\
3 & $\begin{array}{c}\text { Tanah Pemerintah } \\
\text { Tanah Bangunan } \\
\text { Sekolah }\end{array}$ & 2,5 & 2,5 \\
& $\begin{array}{c}\text { Tanah Bangunan } \\
\text { Gereja }\end{array}$ & 1,2 & 0,4 \\
\hline & Jumlah & 300 & 100 \\
\hline
\end{tabular}

Sumber : Kantor Desa Pinabetengan Utara, 2014

Tanah selalu dihubungkan dengan kepemilikan asset rumahtangga, tanah merupakan faktor produksi yang terpenting dalam usaha pertanian. Dalam perkiraan pendapatan masyarakat perdesaan, yang sebagian besar diperoleh di bidang pertanian, tanah sering dijadikan alat mengukur pendapatan. Faktor tanah telah banyak dipergunakan sebagai dasar penduga tingkat kekayaan suatu rumahtangga.

Berdasarkan Tabel 1. dilihat bahwa penggunaan lahan terbesar adalah lahan tegalan atau ladang 186 ha (62\%), hal tersebut menunjukkan bahwa sebagian besar penduduk adalah petani. Pemukiman 102 ha (34\%), tanah pemerintah 7,5 ha $(2,5 \%)$, tanah bangunan sekolah 2,5 ha $(0,8 \%)$, tanah bangunan gereja 2 ha $(0,7 \%)$.

\section{Keadaan Penduduk}

Berdasarkan data yang diperoleh jumlah penduduk di Desa Pinabetengan Utara \pm 1520 jiwa yang terdiri atas 748 jiwa laki-laki dan 772 jiwa perempuan serta rumah tangga $472 \mathrm{KK}$. Perincian jumlah penduduk menurut kelompok umur dapat dilihat pada Tabel. 2 berikut ini. 


\section{Tabel 2. Jumlah Penduduk Menurut Kelompok Umur di Desa Pinabetengan}

\begin{tabular}{cccc}
\hline $\begin{array}{c}\text { No } \\
\cdot\end{array}$ & $\begin{array}{c}\text { Kelompok } \\
\text { Umur }\end{array}$ & $\begin{array}{c}\text { Jumlah } \\
\text { (Orang) }\end{array}$ & Persentase (\%) \\
\hline 1 & $0-6$ & 228 & 15 \\
2 & $7-15$ & 380 & 25 \\
3 & $16-25$ & 304 & 20 \\
4 & $26-60$ & 456 & 30 \\
& & & 10 \\
5 & $\begin{array}{c}61 \text { tahun } \\
\text { keatas }\end{array}$ & 152 & 100 \\
\hline & Jumlah & 1.520 & 10 \\
\hline
\end{tabular}

Sumber : Kantor Desa Pinabetengan Utara, 2014

Dari data tersebut dilihat bahwa kelompok umur 26-60 tahun mendominasi jumlah penduduk yang ada di Desa Pinabetengan Utara.

\section{Mata Pencaharian}

Besarnya potensi tanah pertanian yang dimiliki oleh Desa Pinabetengan Utara akan berpengaruh terhadap mata pencaharian penduduknya. Kondisi lahan yang subur dan iklim yang mendukung mengakibatkan sebagian besar penduduknya bekerja di sektor pertanian. Hal tersebut terlihat dari tingginya persentase penduduk yang bekerja di sektor pertanian baik petani dan buruh tani. Pada Tabel. 3. menunjukan bahwa tingginya persentase mata pencaharian sebagai buruh tani dan petani, menandakan bahwa masyarakat memiliki potensi yang besar di sektor pertanian, sehingga banyak tenaga kerja yang terserap di sektor pertanian, dapat dilihat pada tabel berikut ini.
Tabel. 3. Klasifikasi Penduduk Menurut Jenis Mata Pencaharian di Desa Pinabetengan Utara

\begin{tabular}{cccc}
\hline No. & $\begin{array}{c}\text { Jenis } \\
\text { Pekerjaan }\end{array}$ & $\begin{array}{c}\text { Jumlah } \\
(\text { Orang })\end{array}$ & $\begin{array}{c}\text { Persentase } \\
(\%)\end{array}$ \\
\hline 1 & Petani & 176 & 40 \\
2 & Buruh Tani & 125 & 28,4 \\
3 & $\begin{array}{c}\text { Pegawai } \\
\text { Negeri }\end{array}$ & 88 & 20 \\
4 & Wiraswasta & 11 & 2,5 \\
5 & POLRI & 4 & 0,9 \\
6 & Pensiunan & 14 & 3,2 \\
7 & Dll & 22 & 5 \\
\hline \multicolumn{5}{l}{ Jumber : Kantor Desa Pinabetengan Utara, } \\
2014 & &
\end{tabular}

Rumahtangga yang memiliki lahan pada umumnya memiliki pekerjaan utama sebagai petani, sedangkan rumahtangga yang tidak memiliki lahan biasanya memiliki pekerjaan utama selain bertani. Meskipun demikian, karena desa ini memiliki lahan yang subur untuk pertanian, maka sebagian besar dari rumahtangga yang tidak memiliki lahan akan berusaha melakukan kegiatan bertani dengan cara menyewa lahan untuk digarap. Menurut tabel diatas dapat diuraikan Petani 40\%, Buruh tani 28,4\%, Pegawai Negeri 20\%, Wiraswasta 2,5\%, POLRI 0,9\%, Pensiunan 3,2\%, Dll 5\%. Pekerjaan masyarakat Pinabetengan utara yang termasuk dalam 5\% adalah karyawan BUMN, wartawan, perangkat desa, anggota legislatif, sopir, karyawan swasta, tukang kayu, pemuka agama, bidan, buruh cuci, dan pembantu rumahtangga.

\section{Karakteristik Petani}

Karakteristik petani berdasarkan umur mempengaruhi kemampuan bekerja. Makin 
tinggi umur seseorang maka makin berkurang kemampuan untuk bekerja. Umur responden bervariasi mulai dari 26 tahun sampai pada 79 tahun. Dalam penelitian ini umur responden dibagi menjadi 3 kategori kelompok umur seperti pada Tabel. 4 berikut ini.

Tabel. 4. Umur Petani Responden di Desa Pinabetengan Utara

\begin{tabular}{cccc}
\hline No. & $\begin{array}{c}\text { Umur } \\
\text { (Tahun) }\end{array}$ & $\begin{array}{c}\text { Jumlah } \\
\text { Responden } \\
\text { (Orang) }\end{array}$ & Persentasi (\%) \\
\hline 1 & $26-40$ & 15 & 25 \\
2 & $41-55$ & 23 & 38,3 \\
3 & $56-79$ & 22 & 36,7 \\
\hline & Jumlah & 60 & 100
\end{tabular}

Sumber : Diolah data primer 2016

Pada tabel 4 menunjukan bahwa jumlah petani responden yang berumur 41 - 55 tahun adalah 23 orang $(38,3 \%)$ sehingga dapat dikatakan bahwa sampel petani umumnya termasuk pada golongan produktif. Responden pada umur 56 - 79 tahun adalah 22 orang $(36,7 \%)$ kelompok responden kedua terbanyak ini merupakan kelompok yang sebagian berusia lanjut tapi masih bekerja sebagai petani, sedangkan kelompok umur $26-40$ tahun adalah 15 orang (25\%).

\section{Tingkat Pendidikan}

Pendidikan merupakan indikator yang berperan dalam menentukan status sosial individu masyarakat. Pendidikan erat hubungannya dengan keterampilan kemampuan dan tingkat penghasilan yang diperoleh seseorang. Dengan semakin tinggi pendidikan maka seseorang diharapkan mempunyai wawasan yang lebih luas dibandingkan orang yang memiliki tingkat pendidikan rendah, dapat dilihat pada tabel 5 berikut ini.
Tabel 5. Tingkat Pendidikan Responden di Desa Pinabetengan Utara

\begin{tabular}{cccc}
\hline No. & $\begin{array}{c}\text { Tingkat } \\
\text { Pendidikan }\end{array}$ & $\begin{array}{c}\text { Jumlah } \\
\text { Responden } \\
\text { (orang) }\end{array}$ & $\begin{array}{c}\text { Persentase } \\
(\%)\end{array}$ \\
\hline 1 & SD & 23 & 38,3 \\
2 & SMP & 20 & 33,3 \\
3 & SMA & 16 & 26,7 \\
4 & S1 & 1 & 1,7 \\
\hline & Jumlah & 60 & 100 \\
\hline
\end{tabular}

Sumber : Diolah data Primer. 2016

Data 5 menunjukan bahwa tingkat pendidikan SD 23 orang $(38,3 \%)$, SMP 20 orang $(33,3 \%)$, SMA 16 orang $(26,7 \%)$, S1 1 orang $(1,7 \%)$. Tabel tersebut menunjukan bahwa tingkat pendidikan mempengaruhi pekerjaan responden. Tingkat pendidikan akhir SD memiliki presentase yang besar karena para petani pada umumnya berada di umur 55 tahun keatas yang berarti para petani ini hidup di masa pendidikan yang sulit dijangkau oleh masyarakat yang tinggal di desa. Sementara di jenjang SMP juga masih sedikit yang memiliki pengetahuan sampai jenjang pendidikan tersebut. Demikian di tingkat SMA presentase yang dimiliki masih sedikit, masyarakat masih belum menyadari pentingnya pendidikan. Responden yang bergelar sarjana hanya 1 orang, meskipun sudah pensiun tapi kepala keluarga tersebut masih mengolah lahan pertaniaanya. Melalui penjelasan tersebut dapat disimpulkan bahwa penduduk Desa Pinabetengan masih memiliki tingkat pendidikan yang rendah.

\section{Luas Lahan}

Luas lahan mempengaruhi besar kecilnya produksi hasil tani. Semakin luas lahan pertanian maka semakin efisien lahan tersebut. Petani lahan luas dapat memperoleh pendapatan yang lebih tinggi daripada petani yang mempunyai lahan sempit, karena dengan skala usaha yang luas, juga dapat menggunakan faktor produksi yang lebih besar jumlahnya daripada yang diperoleh petani sempit. 
Tabel 6. menunjukan bahwa sebagian besar petani memiliki luas luas lahan 0,46ha0,8ha dengan 27 Orang (45\%), Pada urutan kedua dengan 23 orang pada 0,1 ha- 0,45 ha presentase $38,34 \%$, dan presentase yang sama $8,33 \%$ pada jumlah petani 5 orang dengan luas lahan 0,81 ha-1,15ha dan 1,16ha-1,5ha, dapat dilihat pada tabel berikut ini.

Tabel 6. Luas Lahan Petani di Desa Pinabetengan Utara

\begin{tabular}{cccc}
\hline $\begin{array}{c}\text { No } \\
\cdot\end{array}$ & $\begin{array}{c}\text { Luas } \\
\text { Lahan } \\
\text { (Ha) }\end{array}$ & $\begin{array}{c}\text { Jumlah } \\
\text { Petani } \\
\text { (Orang) }\end{array}$ & $\begin{array}{c}\text { Persentase } \\
(\%)\end{array}$ \\
\hline 1 & $0,1-0,45$ & 23 & 38,34 \\
2 & $0,46-0,8$ & 27 & 45 \\
3 & $0,81-1,15$ & 5 & 8,33 \\
4 & $1,16-1,5$ & 5 & 8,33 \\
\hline & Jumlah & 60 & 100
\end{tabular}

Sumber : Diolah data Primer. 2016

Diketahui bahwa luas lahan dengan besar 1 ha dimiliki oleh sedikit petani, maka fakta adanya tradisi pembagian tanah yang merupakan warisan turun-temurun keluarga, tanah atau lahan tersebut akan lebih sempit seiring berjalannya waktu. Selain itu ada banyak lahan yang sudah tidak digunakan lagi sebagai faktor produksi tani yang sudah berubah menjadi lahan tidur. Faktor yang menyebabkan adanya lahan tidur ini terdapat pada faktor manusia yang sudah tidak lagi bercocok tanam ataupun sudah tidak produktif lagi. Karena perkembangan teknologi para petani beralih pekerjaan ke sector informal ataupun lainnya.

\section{Komoditas Utama \\ Hasil usaha tani yang ada} dibudidayakan di desa ini jagung, brenebon dan kacang tanah yang menjadi komoditas utama di desa ini. Tanaman ini sesuai dengan suhu, kelembaban dan cuaca di kaki gunung. Komoditas utama di desa dapat dilihat pada tabel 7 berikut ini
Tabel 7. Komoditas Utama Petani di Desa Pinabetengan Utara

\begin{tabular}{ccc}
\hline No. & Komoditas & $\begin{array}{c}\text { Jumlah Petani } \\
\text { (orang) }\end{array}$ \\
\hline 1 & Jagung & 38 \\
2 & Brenebon & 25 \\
3 & Kacang Tanah & 18 \\
4 & Padi & 5 \\
5 & $\begin{array}{c}\text { Sayur dan } \\
\text { Rempah }\end{array}$ & 3 \\
\hline
\end{tabular}

Sumber : Diolah data primer. 2016

Menurut data table 7. komoditas utama masyarakat desa ini pada posisi terbanyak yaitu jagung yaitu 25 orang. Jagung merupakan komoditas utama di desa ini. hampir semua masyarakat menanam jagung, karena besar peluang dijual sebagai bahan baku makanan dan juga makanan ternak. Karena adanya bendi yang menjadi alat transportasi umum masyarakat antar desa maka, jagung sebagai makanan ternak yaitu kuda sangat populer di desa ini. Tanaman ini bisa ditemukan pada kalangan masyarakat yang memiliki kuda atau berprofesi sebagai kusir kuda bendi. Tapi di masyarakat pada umumnya juga banyak yang menanam jagung karena selain bisa dikonsumsi secara pribadi, bisa juga dijual.

Komoditas utama yang ada di urutan kedua yaitu brenebon atau disebut juga dengan kacang merah dengan jumlah petani 20 orang. Brenebon adalah salah satu tanaman kacangkacangan yang sering ditanam di desa ini. Brenebon ditanam pada suhu udara $20^{\circ}-25^{\circ}$. Dipanen setelah tanaman berumur 65 hari dari waktu tanam. Hasil panen kacang brenebon, akan dijual di pasar setelah atau dikonsumsi sendiri setelah melalui pasca panen, seperti pemisahan biji kacang berdasarkan kualitas setelah itu di simpan dengan menggunakan karung goni. Diurutan ketiga komoditas kacang tanah sebanyak 18 orang. Tanaman kacang tanah memerlukan 100 hari hingga masa panen. Pada umumnya kacang yang di panen dalam hasil banyak di jual ke tengkulak dan akan dikonsumsi sendiri jika hanya sedikit. Pada masa panen, tengkulak yang ada biasanya langsung menjemput hasil kacang tanah di kebun pemiliknya. Kacang 
tanah dan kacang brenebon ditanam di waktu yang sama untuk menghemat waktu tanam karena hanya mempunyai selisih 1 bulan masa panen.

Pada posisi keempat tanaman padi dengan banyak responden 5 orang. Para petani di desa ini hanya sedikit yang memiliki sawah untuk menanam padi, karena itu responden yang didapat hanya 5 orang yang bercocok tanam di tanah basah ini. Padi merupakan tanaman musiman yang ditanam setiap 5 bulan. Dan diurutan terakhir komoditas tanaman sayur dan rempah yang memiliki 3 responden petani. Para petani yang termasuk dalam 3 responden ini, adalah para pedagang kaki lima di pasar yang menjual hasil tanaman kebun, seperti sayur-sayuran serta rempah-rempah.

\section{Pendapatan Usaha Tani}

Kesejahteraan rumahtangga petani tergantung pada berapa besar pendapatan yang didapat dari pekerjaan. Pendapatan usahatani yang dimaksud adalah pendapatan bersih dari seluruh hasil tani. Semua hasil tani dihitung secara keseluruhan baik itu dijual atau tidak. Pendapatan petani didapat dari hasil wawancara secara langsung dengan petani.

Pada Tabel 8. dapat dilihat bahwa terdapat 23 orang petani $(38,3 \%)$ yang memiliki pendapatan Rp500.000 - Rp1.325.000. Disusul dengan 25 orang petani $(41,7 \%)$ dengan pendapatan Rp1.325.001 - Rp2.150.000 Diurutan ketiga pendapatan Rp2.150.001 Rp2.975.000, 8 orang $(13,3 \%)$. Dan diurutan terakhir Rp2.975.001 - Rp3.800.000, petani 4 orang $(6,7 \%)$, dapat dilihat pada tabel berikut ini.

\section{Tabel 8. Pendapatan Usaha Tani Petani di Desa Pinabetengan Utara}

\begin{tabular}{cccc}
\hline No. & $\begin{array}{c}\text { Pendapatan } \\
(\mathrm{Rp})\end{array}$ & $\begin{array}{c}\text { Jumlah } \\
\text { Petani } \\
(\text { Orang) }\end{array}$ & $\begin{array}{c}\text { Persentase } \\
(\%)\end{array}$ \\
\hline 1 & $500.000-1.325 .000$ & 23 & 38,3 \\
2 & $1.325 .001-$ & 25 & 41,7 \\
& 2.150 .000 & & \\
3 & $2.150 .001-$ & 8 & 13,3 \\
& 2.975 .000 & & \\
4 & $\begin{array}{c}2.975 .001- \\
3800.000\end{array}$ & 4 & 6,7 \\
\hline & Jumlah & 60 & 100 \\
\hline
\end{tabular}

Sumber : Diolah data primer. 2016

Pendapatan usaha tani diatas adalah hasil bersih setelah di kurangi dengan biaya pengeluaran selama proses usaha tani berlangsung. Biaya-biaya tersebut termasuk pembelian benih, pemupukan, dll. Pada umumnya benih yang di tanam adalah benih pilihan hasil usahatani sendiri, dengan demikian biaya untuk pembelian benih tidak di anggarkan pada biaya pengeluaran. Pendapatan petani dihitung dalam pendapatan sebulan.

\section{Sektor Informal}

Hasil penelitian menunjukan bahwa, semua responden memiliki sumbangan pendapatan lain di luar usaha tani. Adapun pekerjaan yang dilakukan selain usaha tani dapat dilihat pada table 9 berikut ini.

Tabel 9 menunjukan bahwa pekerjaan sektor informal yang dilakukan adalah tukang ojek yaitu sebanyak 22 orang $(36,6 \%)$, ojek adalah salah satu transportasi yang paling banyak diminati semua kalangan masyarakat selain cepat ojek juga menawarkan harga yang relative murah yaitu Rp. 5000 sekali jalan kawangkoan-pinabetengan begitupun sebaliknya, karena itu masyarakat lebih memilih sarana ini untuk menjadi transportasi andalan masyarakat Pinabetengan. Disamping itu untuk menjadi tukang ojek diperlukan kendaraan motor. Rata-rata pengendara ojek ini menggunakan sistem kredit sebagai cara membayar motor, sistem kredit dipilih karena para tukang ojek tidak mampu membeli motor secara langsung atau cash.

Sektor informal kedua bendi yaitu 10 orang (16,6\%), merupakan nama lain dari delman atau dokar ( kereta kuda ) adalah salah satu alat transportasi tradisional yang beroda dua yang tidak menggunakan mesin tetapi menggunakan kuda sebagai penggantinya, dan orang yang menjalankan bendi disebut kusir. Kereta ini dapat menampung 5 orang dewasa dan memasang tarif sekali jalan Rp. 5000 per orang rute kawangkoan - pinabetengan. Aktifitas para kusir bendi biasanya hanya pada hari - hari tertentu seperti hari pasar 3 kali dalam seminggu yaitu hari senin, kamis dan sabtu. Adapula bendi yang beraktifitas di hari biasa tapi hanya $1-2$ bendi saja.

Sektor informal selanjutnya yaitu warung dengan banyak 7 orang dengan presentase $(11,7 \%)$. Warung adalah usaha kecil milik keluarga yang menjual berbagai macam 
barang keperluan sehari-hari seperti sembako (sembilan bahan pokok), minuman, permen, kerupuk, rokok dan kebutuhan rumah tangga lainnya. Usaha warung di desa ini hanya menjual barang dalam jumlah sedikit yang selalu di pasok dari pasar terdekat. Pendapatan dari usaha warung tidak terlalu besar karena setiap barang dijual dengan mengambil keuntungan yang relatif kecil. Pada umumnya lokasi warung berada dekat rumah bahkan ada juga yang sengaja diposisikan didalam rumah. Warung makan memiliki 4 orang responden $(6,7 \%)$ yang merupakan salah satu pekerjaan di sektor informal di desa pinabetengan utara. Kantin di desa sangat berbeda dengan kantin yang ada di perkotaan, dengan bangunan dan lokasi yang sangat berbeda kantin di perkotaan erat kaitannya dengan kantin sekolah, kantin rumah sakit, yang berada dalam sebuah gedung umum yang sering digunakan. Makanan yang disediakan kantin haruslah bersih dan halal, jenis-jenis makanan yang disediakan harus memenuhi 4 sehat 5 sempurna, biasanya para pelanggan harus mengantri dalam sebuah jalur yang disediakan. Pada umumnya kantin menjadi tempat berkumpul tempat bersosialisasi para pembeli. Pesan ambil bayar duduk mungkin merupakan prinsip para pengguna fasilitas kantin di perkotaan.

Kantin di pedesaan adalah tempat menjual makanan dan minuman, dimana kantin yang dimaksud di desa ini adalah kantin yang menjual makanan seperti: mie, tinutuan, pisang goreng dan gorengan lainnya. Harga untuk per porsi Rp. 6000 dan pisang goreng Rp. 1000/biji.

Tukang (bas) 8 orang $(13,3 \%)$ berada pada posisi keempat. Pekerjaan ini hanya mengandalkan pemborong bangunan atau bahkan bas borong. Tukang adalah keahlian khusus yang dipunyai seperti keahlian turuntemurun keluarga. Tukang juga terbagi menjadi 2 yaitu tukang kayu dan tukang batu. Menurut survey pekerjaan sebagai tukang rata-rata 3 kali dalam 1 tahun bahkan adapula yang hanya 2 kali dalam setahun, disewa selama 1-4 bulan kerja penuh. Dengan gaji Rp. 40.000 - Rp. 60.000 per hari. Diluar kerja borongan, biasanya tukang mengerjakan rumah dibawah perintah kepala tukang.

Sektor informal keenam yaitu pedagang pasar 4 orang $(6,7 \%)$. Pedagang pasar adalah pedagang yang menjual barang dagangan di pasar seperti sayur, rempah-rempah, mie, serta pakaian bekas. Pasar kawangkoan menjadi satusatunya tempat berdagang para penjual sayur. Dalam seminggu 1-2 kali berjualan karena hasil tani yang tidak pasti sesuai dengan iklim dan cuaca yang ada. Penjual mie satu satunya di Pinabetengan utara mendagangkan mie di pasar tradisional kawangkoan. Harga mie Rp. $7000 / \mathrm{kg}$ yang rata-rata setiap harinya dijual 25$40 \mathrm{~kg}$. Sesuai jadwal pasar kawangkoan hanya dibuka 3 kali seminggu begitu pula para pedagang pasar. Pedagang pasar yang menjadi responden yaitu pedagang pakaian bekas yang memasok dari pasar Tomohon harga 1bal pakaian bekas Rp. 300.000. kemudian dijual kembali di pasar kawangkoan. Keuntungan yang didapat 2 kali lipat dari uang pokok.

Tukang jahit dengan responden 2 orang presentase $(3,3 \%)$ adalah usaha sampingan selain usahatani. Usaha ini membutuhkan keahlian khusus agar mahir mengerjakannya. Pada umumnya usaha ini adalah usaha keluarga yang biasanya bertempat di rumah sendiri. Pendapatan perbulan Rp. 500.000 - Rp. 700.000. Harga yang ditawarkan relatif murah karena masih dalam pedesaan. Usaha lainnya pedagang keliling yaitu pedagang bakso keliling sebanyak 1 orang $(1,7 \%)$. Pedagang bakso mengelilingi seluruh desa pinabetengan pada sore pkl 16.30 - 21.00 malam, setiap hari senin, rabu dan sabtu. Bakso per porsi Rp.8000.

Usaha bengkel 1 responden dengan presentase $(1,7 \%)$. Sesuai dengan usaha yang digeluti perbengkelan kemampuan di bidang memang tidak menghasilkan pendapatan yang banyak tapi usaha untuk menolong orang di bidang ini sangat membantu di desa. Buruh cuci 1 orang $(1,7 \%)$. Seorang ibu rumah tangga yang menambah pendapatan selain usahatani menjadi buruh cuci yang disewa perhari Rp. 50.000 Rp. 75.000, biasanya dalam sebulan mendapat pemasukan Rp. 375.000.

\section{Pendapatan Sektor Informal}

Pendapatan sector informal dapat dihitung dengan mengalikan antara berapa kali kerja dalam 1 bulan dikali dengan upah per hari kerja. Pekerjaan yang tidak memiliki perhitungan jam kerja tidak perlu dilakukan perhitungan tapi dihitung seberapa sering atau berapa kali dilakukan pekerjaan sampingan di sektor informal dalam satu bulan, maka 
dikalikan dengan upah per hari yang sudah diketahui. Untuk menghitung pendapatan yang merupakan hasil kerja selama satu bulan kemudian di akumulasi dengan pendapatan usahatani. Pendapatan sektor informal dibagi dalam 3 strata yaitu $\leq 1 \mathrm{jt}, 1,1 \mathrm{jt}-2 \mathrm{jt}, 2,1 \mathrm{jt}-3 \mathrm{jt}$. Pembagian strata ini dapat mempermudah diketahuinya sector mana yang memberi kontribusi terbesar terhadap pendapatan petani di desa ini.

Tabel 10. menunjukan bahwa pendapatan sektor informal untuk tukang ojek 22 orang, bendi 10 orang, warung 5 orang, warung makan 5 orang, tukang (bas) 10 orang, pedagang kaki lima 4 orang, penjahit 1 orang, bengkel 1 orang, pedagang keliling 1 orang, buruh cuci 1 orang, dapat dilihat pada tabel berikut ini. Pendapatan sektor informal pada tabel 11 menunjukan bahwa strata pendapatan $\leq 1$ jt yaitu sebanyak 37 orang, pendapatan $1 \mathrm{jt}-2 \mathrm{jt}$ sebanyak 23 orang dan pendapatan 2,1jt-3jt tidak mempunyai responden.

Sektor informal yang umumnya adalah usaha keluarga memiliki pendapatan yang cukup untuk menunjang kesejahteraan keluarga tani. Pekerjaan sampingan ini yang dikerjakan para petani di waktu senggang. Maka pendapatan maksimal yang didapat hanya berada pada strata kedua yaitu 1jt-2jt. Sedangkan banyaknya responden strata pertama diakibatkan karena adanya faktor waktu dan kesempatan bekerja di sektor informal.

Pendapatan ojek pada strata $\leq 1 \mathrm{jt}$ terdapat 7 orang $(31,8 \%)$, strata $1,1 \mathrm{jt}-2 \mathrm{jt}$ terdapat 15 orang $(68,2)$, strata $2,1 \mathrm{jt}-3 \mathrm{jt}$ tidak terdapat responden. Pendapatan di strata $1,1 \mathrm{jt}-$ 2 jt memiliki jumlah responden lebih banyak dibandingkan strata lainnya. Banyaknya pendapatan yang didapat, disebabkan karena masih sedikitnya ojek yang ada, serta masih sedikitnya saingan orang yang ingin melakukan pekerjaan tukang ojek. Besar kecilnya pendapatan tergantung pada seberapa banyak hari/jam yang di pakai melakukan pekerjaan tukang ojek. Pekerjaan bendi, strata $\leq 1 \mathrm{jt} 7$ orang $(70 \%)$, strata $1,1 \mathrm{jt}-2 \mathrm{jt}$ terdapat 3 orang $(30 \%)$, strata $2,1 \mathrm{jt}-3 \mathrm{jt}$ tidak terdapat responden. Responden terbanyak terdapat pada strata $\leq 1 \mathrm{jt}$. Sama seperti sektor informal ojek, pendapatan bendi tergantung pada berapa kali/hari melakukan pekerjaan. Sektor informal warung pendapatan $\leq 1 \mathrm{jt} 4$ orang $(80 \%)$, strata $1,1 \mathrm{jt}-2 \mathrm{jt}$ terdapat 1 orang (20\%), strata $2,1 \mathrm{jt}-3 \mathrm{jt}$ tidak terdapat responden. Warung makan, pada strata $\leq 1 \mathrm{jt} 4$ orang $(80 \%)$, strata $1,1 \mathrm{jt}-2 \mathrm{jt}$ terdapat 1 orang $(20 \%)$, strata $2,1 \mathrm{jt}-3 \mathrm{jt}$ tidak terdapat responden. Warung dan warung makan di sebut juga usaha keluarga yang di kerjakan oleh sebagian bahkan seluruh anggota keluarga. Pendapatan yang didapat, dipengaruhi oleh tempat warung berada, aneka ragam jenis barang yang dijual, banyaknya saingan yang ada dan banyaknya pembeli yang dating membeli. Pekerjaan tukang (bas) pendapatan $\leq$ $1 \mathrm{jt} 8$ orang $(80 \%)$, strata $1,1 \mathrm{jt}-2 \mathrm{jt}$ terdapat 2 orang $(20 \%)$, strata $2,1 \mathrm{jt}-3 \mathrm{jt}$ tidak terdapat responden. Pendapatan para tukang (bas) dipengaruhi oleh banyaknya waktu yang dipakai untuk melakukan kerja serta besarnya gaji hari/minggu/bulan yang di minta dalam suatu pekerjaan. Pedagang kaki lima di desa Pinabetengan utara dapat dilihat pada, pendapatan $\leq 1 \mathrm{jt} 3$ orang $(75 \%)$, strata $1,1 \mathrm{jt}-2 \mathrm{jt}$ terdapat 1 orang $(25 \%)$, strata $2,1 \mathrm{jt}-3 \mathrm{jt}$ tidak terdapat responden. Pendapatan di sektor informal yang didapat, masih pada strata $\leq 1 \mathrm{jt}$ menunjukan bahwa meskipun PKL hanya dilakukan oleh sedikit orang namun pendapatan, masih dibawah 1jt. Pekerjaan ini sangat dipengaruhi oleh banyaknya pembeli serta tempat transaksi jual beli, yang berada di kerumunan saingan penjual. Sektor informal tukang jahit hanya dimiliki oleh 1 orang pada strata $\leq 1 \mathrm{jt}$, menunjukan bahwa sedikit orang yang berlagganan memakai jasa penjahit karena sudah terbiasa dengan pakaian yang dijual secara langsung. Sedikitnya para pemakai jasa ini mempengaruhi pendapatan.

Pendapatan pedagang keliling, dimiliki oleh 1 orang pada strata $\leq 1 \mathrm{jt}$. Pedagang keliling hanya berkeliling 3hari/minggu karena itu pendapatannya juga tergantung pada berapa kali berjualan juga keberuntungan yang didapat, banyaknya peminat yang membeli. Bengkel sebagai pekerjaan sektor informal hanya dimiliki oleh 1 orang dengan pendapatan pada strata $\leq 1 \mathrm{jt}$. Bengkel ini diminati jika ada alatalat tani yang rusak juga transportasi desa (bendi) yang mengalami kerusakan. Montir ini hanya melakukan pekerjaan jika diperlukan oleh pengunjung.Pekerjaan sektor informal buruh cuci, hanya di lakukan oleh 1 orang dengan pendapatan $\leq 1$ jt. Buruh cuci mempunyai pendapatan jika diperlukan oleh peminat. Pendapatan yang dimilik tidak meneatap per bulan. 


\section{Kontribusi Pendapatan Sektor Informal}

Kontribusi pendapatan sektor informal pada pendapatan petani di desa pinabetengan utara dapat dilihat pada Tabel 11.

Total pendapatan Rp. 163,070,000 rata-rata total pendapatan $\mathrm{Rp} 2,717,833$. Ratarata kontribusi sektor informal terhadap pendapatan petani yaitu $41,10 \%$. Hal ini menunjukan pekerjaan di sektor informal di desa Pinabetengan utara Kecamatan Tompaso barat dapat dikatakan sebagai usaha sampingan. Pendapatan pekerjaan sektor informal merupakan pendapatan tambahan untuk kesejahteraan keluarga.

Tabel 9. Pekerjaan Sektor Informal di Desa Pinabetengan Utara

\begin{tabular}{|c|c|c|c|}
\hline No. & $\begin{array}{l}\text { Pekerjaan } \\
\text { Sektor } \\
\text { Informal }\end{array}$ & $\begin{array}{c}\text { Jumlah } \\
\text { Responden } \\
\text { (Orang) }\end{array}$ & $\begin{array}{c}\text { Persentasi } \\
(\%)\end{array}$ \\
\hline 1 & Ojek & 22 & 36,6 \\
\hline 2 & Bendi & 10 & 16,6 \\
\hline 3 & Warung & 7 & 11,7 \\
\hline 4 & $\begin{array}{l}\text { Warung } \\
\text { makan }\end{array}$ & 4 & 6,7 \\
\hline 5 & Tukang (bas) & 8 & 13,3 \\
\hline 6 & $\begin{array}{l}\text { Pedagang } \\
\text { Pasar }\end{array}$ & 4 & 6,7 \\
\hline 7 & Tukang Jahit & 2 & 3,3 \\
\hline 8 & $\begin{array}{l}\text { Pedagang } \\
\text { Keliling }\end{array}$ & 1 & 1,7 \\
\hline 9 & Bengkel & 1 & 1,7 \\
\hline 10 & Buruh Cuci & 1 & 1,7 \\
\hline & Jumlah & 60 & 100 \\
\hline
\end{tabular}

Sumber : Diolah data primer. 2016
Tabel 10. Pendapatan Sektor Informal di Desa Pinabetengan Utara

\begin{tabular}{|c|c|c|c|c|}
\hline \multirow[b]{2}{*}{ No. } & \multirow[b]{2}{*}{$\begin{array}{l}\text { Sektor } \\
\text { Informal }\end{array}$} & \multicolumn{3}{|c|}{ Pendapatan (Rp) } \\
\hline & & Strata & $\begin{array}{l}\text { Jumlah } \\
\text { (orang) }\end{array}$ & $\begin{array}{l}\text { Persentase } \\
(\%)\end{array}$ \\
\hline \multirow{3}{*}{1.} & \multirow{3}{*}{ Ojek } & $\leq 1 \mathrm{jt}$ & 7 & 31,8 \\
\hline & & $1,1 \mathrm{jt}-2 \mathrm{jt}$ & 15 & 68,2 \\
\hline & & $2,1 \mathrm{jt}-3 \mathrm{jt}$ & - & - \\
\hline \multirow{3}{*}{2.} & \multirow{3}{*}{ Bendi } & $\leq 1 \mathrm{jt}$ & 7 & 70 \\
\hline & & $1,1 \mathrm{jt}-2 \mathrm{jt}$ & 3 & 30 \\
\hline & & $2,1 \mathrm{jt}-3 \mathrm{jt}$ & - & - \\
\hline \multirow{3}{*}{3.} & \multirow{3}{*}{ Warung } & $\leq 1 \mathrm{jt}$ & 4 & 80 \\
\hline & & $1,1 \mathrm{jt}-2 \mathrm{jt}$ & 1 & 20 \\
\hline & & $2,1 \mathrm{jt}-3 \mathrm{jt}$ & - & - \\
\hline \multirow{3}{*}{4.} & \multirow{3}{*}{$\begin{array}{l}\text { Warung } \\
\text { Makan }\end{array}$} & $\leq 1 \mathrm{jt}$ & 4 & 80 \\
\hline & & $1,1 \mathrm{jt}-2 \mathrm{jt}$ & 1 & 20 \\
\hline & & $2,1 \mathrm{jt}-3 \mathrm{jt}$ & - & - \\
\hline \multirow{3}{*}{5.} & \multirow{3}{*}{$\begin{array}{l}\text { Tukang } \\
\text { (bas) }\end{array}$} & $\leq 1 \mathrm{jt}$ & 8 & 80 \\
\hline & & $1,1 \mathrm{jt}-2 \mathrm{jt}$ & 2 & 20 \\
\hline & & $2,1 \mathrm{jt}-3 \mathrm{jt}$ & - & - \\
\hline \multirow{3}{*}{6.} & \multirow{3}{*}{$\begin{array}{c}\text { Pedagang } \\
\text { Kaki Lima }\end{array}$} & $\leq 1 \mathrm{jt}$ & 3 & 75 \\
\hline & & $1,1 \mathrm{jt}-2 \mathrm{jt}$ & 1 & 25 \\
\hline & & $2,1 \mathrm{jt}-3 \mathrm{jt}$ & - & - \\
\hline \multirow{3}{*}{7.} & \multirow{3}{*}{$\begin{array}{l}\text { Tukang } \\
\text { jahit }\end{array}$} & $\leq 1 \mathrm{jt}$ & 1 & 100 \\
\hline & & $1,1 \mathrm{jt}-2 \mathrm{jt}$ & - & - \\
\hline & & $2,1 \mathrm{jt}-3 \mathrm{jt}$ & - & - \\
\hline \multirow{3}{*}{8.} & \multirow{3}{*}{$\begin{array}{l}\text { Pedagang } \\
\text { keliling }\end{array}$} & $\leq 1 \mathrm{jt}$ & 1 & 100 \\
\hline & & $1,1 \mathrm{jt}-2 \mathrm{jt}$ & - & - \\
\hline & & $2,1 \mathrm{jt}-3 \mathrm{jt}$ & - & - \\
\hline \multirow{3}{*}{9.} & \multirow{3}{*}{ Bengkel } & $\leq 1 \mathrm{jt}$ & 1 & 100 \\
\hline & & $1,1 \mathrm{jt}-2 \mathrm{jt}$ & - & - \\
\hline & & $2,1 \mathrm{jt}-3 \mathrm{jt}$ & - & - \\
\hline \multirow{4}{*}{10.} & \multirow{3}{*}{ Buruh cuci } & $\leq 1 \mathrm{jt}$ & 1 & 100 \\
\hline & & $1,1 \mathrm{jt}-2 \mathrm{jt}$ & - & \\
\hline & & $2,1 \mathrm{jt}-3 \mathrm{jt}$ & - & - \\
\hline & Jumlah & & 60 & $100 \%$ \\
\hline
\end{tabular}

Tabel 11. Kontribusi Pendapatan Sektor Informal Pada Pendapatan Petani di Desa Pinabetengan Utara

\begin{tabular}{ccccc}
\hline No. & Pendapatan & $(\mathrm{Rp})$ & Rata-rata & $(\%)$ \\
\hline 1. & Usahatani & $96,050,000$ & $1,600,833$ & \\
2. & $\begin{array}{c}\text { Sektor } \\
\text { Informal }\end{array}$ & $67,020,000$ & $1,117,000$ & $\begin{array}{c}41.10 \\
\%\end{array}$ \\
\hline & $\begin{array}{c}\text { Total } \\
\text { Pendapatan }\end{array}$ & $163,070,000$ & $2,717,833$ & $100 \%$
\end{tabular}

Sumber : Diolah data primer 2016 


\section{KESIMPULAN DAN SARAN}

Kesimpulan

Berdasarkan hasil penelitian yang telah dilaksanakan, maka dapat ditarik kesimpulan Kontribusi pendapatan sektor informal terhadap total pendapatan rumah tangga sebesar $41,10 \%$ dengan rata-rata pendapatan usahatani di desa Pinabetengan utara Kecamatan Tompaso barat Rp. 1.600.833/bulan, rata-rata pendapatan sektor informal Rp. 1.177.000/bln. Sehingga rata-rata total pendapatan Rp. 2.717.833.

\section{Saran}

Untuk masyarakat petani yang memiliki waktu senggang disaat bertani sebaiknya mengalokasikan waktu senggang sebaiknya memiliki pekerjaan di sektor informal yang tidak menganggu waktu kerja tani. Selain itu pendapatan yang dimiliki dapat membantu perekonomian keluarga tani.

\section{DAFTAR PUSTAKA}

Agustina, D. 1994. Analisis Alokasi Waktu Tenaga Kerja dan Peluang Kerja Rumahtangga Pedesaan. Skripsi. Fakultas Pertanian, Institut Pertanian Bogor, Bogor.

Arsyad, L, 1999, Pengantar Perencanaan dan Pembangunan Ekonomi Daerah, Edisi Pertama, Penerbit BPFE

Lembong. B. 2013. Ekonomi Kerakyatan Dan Nasional Ekonomi. PT. Dharma Karsa Utama. Jakarta.

Nazir, M. 2003. Metode Penelitian. Ghalia Indonesia

Nurmanaf, A. R. 2006. Peranan sektor luar pertanian terhadap kesempatan dan pendapatan di pedesaan berbasis lahan kering. Jurnal

Payaman .J.S (1996). Peranan Penelitian Ketenagakerjaan Dalam Pengembangan Sumberdaya Manusia. Himpunan Pembina Sumberdaya Manusia Indonesia.
Triyani, M. 2004. Keragaan Ekonomi Industri Tempe Skala Rumahtangga (Studi

Kasus Desa Citeureup Kecamatan Citeureup Kabupaten Bogor). Skripsi.Fakultas Pertanian, Institut Pertanian Bogor, Bogor.

Zahri, I. 2004. Distribusi Pendapatan dan Hubungannya dengan Alokasi Tenaga Kerja Petani Plasma PIR Kelapa Sawit di Sumatera Selatan. Jurnal Agribisnis dan Industri Pertanian, Volume 3, Nomor 1, halaman $13-18$ 